\title{
Start-Up of Anammox SBR from Non-Specific Inoculum and Process Acceleration Methods by Hydrazine
}

\author{
Ivar Zekker ${ }^{1, *}$, Oleg Artemchuk ${ }^{1}$, Ergo Rikmann ${ }^{1}$, Kelvin Ohimai ${ }^{1}$, Gourav Dhar Bhowmick ${ }^{2}$, \\ Makarand Madhao Ghangrekar ${ }^{2}$, Juris Burlakovs ${ }^{3}$ (D) and Taavo Tenno ${ }^{1}$ (D) \\ 1 Institute of Chemistry, University of Tartu, 14a Ravila St., 50411 Tartu, Estonia; \\ Oleg.artemchuk@gmail.com (O.A.); Ergo.rikmann@gmail.com (E.R.); kelvin.ohimai@gmail.com (K.O.); \\ taavo.tenno@ut.ee (T.T.) \\ 2 Department of Agricultural and Food Engineering, Indian Institute of Technology Kharagpur, \\ Kharagpur 721302, India; gourav.dhar@gmail.com (G.D.B.); ghangrekar@civil.iitkgp.ernet.in (M.M.G.) \\ 3 Department of Environmental Science, University of Latvia, Jelgavas Street 1, LV-1004 Riga, Latvia; \\ juris@geo-it.lv \\ * Correspondence: ivar.zekker@ut.ee
}

Citation: Zekker, I.; Artemchuk, O.; Rikmann, E.; Ohimai, K.; Dhar Bhowmick, G.; Madhao Ghangrekar, M.; Burlakovs, J.; Tenno, T. Start-Up of Anammox SBR from Non-Specific Inoculum and Process Acceleration Methods by Hydrazine. Water 2021, 13, 350. https://doi.org/10.3390/ w13030350

Academic Editor: Maria Gavrilescu Received: 30 December 2020

Accepted: 26 January 2021

Published: 30 January 2021

Publisher's Note: MDPI stays neutral with regard to jurisdictional claims in published maps and institutional affiliations.

Copyright: (c) 2021 by the authors. Licensee MDPI, Basel, Switzerland. This article is an open access article distributed under the terms and conditions of the Creative Commons Attribution (CC BY) license (https:// creativecommons.org/licenses/by/ $4.0 /)$.

\begin{abstract}
Biological nutrient removal from wastewater to reach acceptable levels is needed to protect water resources and avoid eutrophication. The start-up of an anaerobic ammonium oxidation (anammox) process from scratch was investigated in a $20 \mathrm{~L}$ sequence batch reactor (SBR) inoculated with a mixture of aerobic and anaerobic sludge at $30 \pm 0.5^{\circ} \mathrm{C}$ with a hydraulic retention time (HRT) of 2-3 days. The use of $\mathrm{NH}_{4} \mathrm{Cl}, \mathrm{NaNO}_{2}$, and reject water as nitrogen sources created different salinity periods, in which the anammox process performance was assessed: low $\left(<0.2 \mathrm{~g}^{\circ} \mathrm{Cl}^{-} / \mathrm{L}\right)$, high (18.2 $\mathrm{g}$ of $\left.\mathrm{Cl}^{-} / \mathrm{L}\right)$, or optimum salinity $\left(0.5-2 \mathrm{~g} \mathrm{of} \mathrm{Cl}^{-} / \mathrm{L}\right)$. Reject water feeding gave the optimum salinity, with an average nitrogen removal efficiency of $80 \%$, and a TNRR of $0.08 \mathrm{~kg} \mathrm{~N} / \mathrm{m}^{3} / \mathrm{d}$ being achieved after 193 days. The main aim was to show the effect of a hydrazine addition on the specific anammox activity (SAA) and denitrification activity in the start-up process to boost the autotrophic nitrogen removal from scratch. The effect of the anammox intermediate hydrazine addition was tested to assess its concentration effect (range of 2-12.5 $\mathrm{mg}$ of $\mathrm{N}_{2} \mathrm{H}_{4} / \mathrm{L}$ ) on diminishing denitrifier activity and accelerating anammox activity at the same time. Heterotrophic denitrifiers' activity was diminished by all hydrazine additions compared to the control; $5 \mathrm{mg}$ of $\mathrm{N}_{2} \mathrm{H}_{4} / \mathrm{L}$ added enhanced SAA compared to the control, achieving an SAA of $0.72( \pm 0.01) \mathrm{mg} \mathrm{N} / \mathrm{g}$ MLSS/h, while the test with $7.5 \mathrm{mg}$ of $\mathrm{N}_{2} \mathrm{H}_{4} / \mathrm{L}$ reached the highest overall SAA of $0.98( \pm 0.09) \mathrm{mg} \mathrm{N} \mathrm{g} / \mathrm{MLSS} / \mathrm{h}$. The addition of trace amounts of hydrazine for $6 \mathrm{~h}$ was also able to enhance SAA after inhibition by organic carbon source sodium acetate addition at a high $\mathrm{C} / \mathrm{N}$ ratio of $10 / 1$. The start-up of anammox bacteria from the aerobic-anaerobic suspended biomass was successful, with hydrazine significantly accelerating anammox activity and decreasing denitrifier activity, making the method applicable for side-stream as well as mainstream treatment.
\end{abstract}

Keywords: anammox; reject water; salinity; hydrazine; granular biomass; anammox activity; nitrogen removal

\section{Introduction}

The removal of nutrients from wastewater to acceptable thresholds is essential for the protection of water bodies from algal blooms and from subsequent eutrophication, which may lead to reduced dissolved oxygen (DO) concentration and cause the death of life forms [1,2]. The global concern for environmental protection has given impetus to the implementation of stricter effluent standards and this, in turn, has driven the innovation in technologies of nitrogen removal from wastewater. One of the major advancements in nutrient removal was the discovery of the anaerobic ammonium oxidation (anammox) 
process, which occurs under anoxic conditions, and is characterized by the anoxic oxidation of ammonium to $\mathrm{N}_{2}$ gas, with nitrite serving as an electron acceptor [3]:

$\mathrm{NH}_{4}{ }^{+}+1.32 \mathrm{NO}_{2}{ }^{-}+0.066 \mathrm{HCO}_{3}{ }^{-}+0.13 \mathrm{H}^{+} \rightarrow 1.02 \mathrm{~N}_{2}+0.26 \mathrm{NO}_{3}{ }^{-}+0.066 \mathrm{CH}_{2} \mathrm{O}_{0.5} \mathrm{~N}_{0.15}+2.03 \mathrm{H}_{2} \mathrm{O}$

The anammox process shows a high autotrophic total nitrogen removal efficiency (TNRE) (up to 88\%), and low operational costs (about $60 \%$ lower than for nitrification/ denitrification); it has no requirement for an addition of organic carbon, has low emission of greenhouse gases $\left(\mathrm{CO}_{2} / \mathrm{N}_{2} \mathrm{O}\right)$, and has low sludge production compared to nitrificationdenitrification processes [4]. Anammox process-based treatment facilities can achieve a high total nitrogen removal rate (TNRR) of $9 \mathrm{~kg} \mathrm{~N} / \mathrm{m}^{3} / \mathrm{d}$ [5]. Several nutrient removal processes have been successfully started by partial nitration and denitrification (PND) processes within 315 days, yielding a TNRE of $98.5 \%$ [6]. The slow growth rate has driven the quest for optimal conditions for the cultivation and growth of anammox bacteria [7,8]. As most of the anammox technologies are patented and expensive, the possibilities of cultivation of anammox bacteria using different inocula have been reported [9,10]. Inoculum from municipal wastewater provides aerobic and anaerobic bacteria, enhancing anammox startup. As the acquisition of the most suitable inoculum is expensive, anaerobic sludge can be efficiently used for the start-up of anammox bacteria cultivation, ending with a home-grown biomass more adapted to local wastewater conditions [11].

The development of an anammox biomass has shown advantages for use in the suspended sludge-based sequence batch reactor (SBR) system, which include: low cost, flexibility of operation, compactness, high efficiency [12], stability, and resiliency, with a short biomass recovery time [13]. Ammonium oxidizing bacteria (AOB) can be found at the surface of the biomass, where they consume DO, and, within an anoxic zone, anaerobic bacteria are represented, facilitating the co-existence of AOBs and anammox bacteria [14].

The salinity optimum at 3-10 $\mathrm{g} \mathrm{NaCl} / \mathrm{L}$ has promoted the formation of anammox granular sludge, whereas higher salinities $(30 \mathrm{~g} \mathrm{NaCl} / \mathrm{L})$ [15]. have inhibited the anammox process [16]. Additionally, nitrite oxidizing bacteria, which compete for nitrite together with anammox bacteria, are inhibited at higher salinities (30 g NaCl/L) [15]. Increased salinity results in a high osmotic pressure for bacteria, which can lead to dormancy or plasmolysis of bacteria. As compared to denitrifiers, anammox bacteria have shown acclimatization to high salinity conditions [16,17].

Nitrite plays an important role as an electron acceptor in the anammox process. Although the exerted inhibitory effect by $\mathrm{NO}_{2}{ }^{-}$is reversible in the short-term [18], it can be recovered more effectively by hydrazine addition [19]. The anammox process itself is affected by hydrazine $\left(\mathrm{N}_{2} \mathrm{H}_{4}\right)$ and nitric oxide (NO), as these anammox intermediates at optimal concentration promote TNRR [20].

Externally added hydrazine is utilized in the production of extra energy for anammox bacteria, and this consequently helps in the acceleration of growth of the anammox biomass during the start-up process. The external addition of $\mathrm{N}_{2} \mathrm{H}_{4}$ limits the accumulation of $\mathrm{NO}_{3}{ }^{-}$and the production of an important greenhouse gas, $\mathrm{N}_{2} \mathrm{O}$ [21]. The additional $\mathrm{N}_{2} \mathrm{H}_{4}$ may directly alter the anammox stoichiometry so that more nitrite is used per mole of converted ammonium, since more protons and electrons are transferred for nitrite reduction, whereas nitrate production is decreased in anabolism. This change in the anammox stoichiometry is independent of the metabolic activity of other functional bacteria present in the consortium. Anammox bacteria are able to uniquely metabolize and use hydrazine as an energy source [20]. The use of a non-specific aerobic, anaerobic, and fermentation biomass has found little application in the cultivation of anammox bacteria so far, with the use of the anammox intermediate hydrazine to accelerate the anammox process and de-stimulate other rapidly overgrowing heterotrophic bacteria activity. Hydrazine addition enabling shortening of the non anammox-specific biomass cultivation time has not been given much attention. Some works have highlighted the positive effect of hydrazine enhancing and improving anammox biomass TNRR, with an optimum concentration of $4 \mathrm{mg}$ of $\mathrm{N}_{2} \mathrm{H}_{4}$ /L [22]. Experiments performed within an anammox system showed that the addition of $2-5 \mathrm{mg}$ of $\mathrm{N}_{2} \mathrm{H}_{4} / \mathrm{L}$ significantly improved TNRE $(p<0.01)$, and increased 
the process stability. This hydrazine concentration range has stimulated anammox bacteria without harming AOBs, but has inhibited nitrite oxidizing bacteria (NOBs) [23]. However, systematic studies of the effect of hydrazine on all major groups of bacteria involved in nitrogen removal (anammox, AOBs, NOBs, denitrifiers) at once are lacking. Hydrazine addition contributes to a rapid recovery of the anammox biomass from nitrite inhibition, but its ameliorating effect in the case of detrimental effects resulting from excessive salinity is also possible. A considerably higher hydrazine concentration $\left(>15 \mathrm{mg} \mathrm{of} \mathrm{N}_{2} \mathrm{H}_{4} / \mathrm{L}\right.$ ) was observed to slow down the nitrogen removal process (nitrite oxidation, denitrification, anammox), which is possibly attributable to the inhibitory effect $[19,22,23]$. If hydrazine dosing allows a significant reduction in the start-up time and in the recovery time of the inhibition-damaged anammox biomass, it can be easily applied in a WWTP using a solution of hydrazine sulfate (also known as hydrazinium hydrogen sulfate, $\mathrm{N}_{2} \mathrm{H}_{6} \mathrm{SO}_{4}$ ), delivered by a simple dosage pump for liquid chemicals. Hydrazine sulfate is preferred to pure hydrazine, because it is not volatile, poses lesser risks, is easier to handle, and is less susceptible to atmospheric oxidation in storage.

This study undertakes the start-up of anammox bacteria with non-specific inoculum as seeding sludge (anaerobic and aerobic sludge) using hydrazine addition in the single sequence batch reactor (SBR). The main objective is to evaluate the effect of hydrazine addition on the specific anammox activity (SAA) and denitrification activity during different stages of the start-up process in order to accelerate the overall start-up of autotrophic nitrogen removal from scratch. An additional objective is to evaluate the effect of salinity on the start-up process and overcome the detrimental effect of excess salinity with hydrazine.

\section{Materials and Methods}

\subsection{Experimental Setup}

In this work, an SBR system with an active volume of $20 \mathrm{~L}$ was used, with a reactor height of $52 \mathrm{~cm}$ and inner diameter of $25 \mathrm{~cm}$. The first stage of the reactor work was feeding with $\mathrm{NaNO}_{2}$ (30 g of N/L), $\mathrm{NH}_{4} \mathrm{Cl}(24 \mathrm{~g}$ of N/L), or reject water, using a feeding pump (Seko, Italy). The SBR was operated at stirring rates of $200( \pm 5)$ rotations per minute (rpm), using a time relay interval of $15 \mathrm{~min}$ to allow the intermittent mixing of the biomass and ensure low oxygen amounts entering into the reactor. The bioreactor had a settling phase of $30 \mathrm{~min}$. Subsequently, the removal of the effluent was done. The temperature within the Plexiglas reactor during reactor operation and batch tests was $30( \pm 0.5){ }^{\circ} \mathrm{C}$, and the hydraulic retention time (HRT) was 2-3 days. The reactor was connected with a water jacket. HRT was maintained with a water exchange of $10 \mathrm{~L}$ or an equivalent amount done after the settling phase to reduce the effect of high salt $[24,25]$ and nitrate concentration in the bioreactor.

\subsection{Inoculum and Operation Conditions in the Bioreactor}

A mixed sludge obtained from the nitrification-denitrification process and the anaerobic digestion stage of the municipal wastewater treatment plant (WWTP), Estonia (100,000 p.e.), was used as a seed. Five L of activated and anaerobic sludge were added to the SBR at the start-up. The amount of the biomass in the reactor was determined as a mixed liquor-suspended solid (MLSS) from the start of the cultivation process, and subsequently monthly as the start-up process continued. The initial MLSS concentration after inoculation was $10.8( \pm 0.25) \mathrm{g} / \mathrm{L}$, and the MLSS was $9.0( \pm 0.05) \mathrm{g} / \mathrm{L}$ after a week, diminishing during operation due to the nitrifying and denitrifying organisms' washout into the effluent. After two weeks, the bioreactor was covered by a plastic cover to avoid nitrite oxidation to nitrate. The salinity level and nitrogen species $\mathrm{NO}_{2}{ }^{-}$and $\mathrm{NH}_{4}{ }^{+}$concentrations were regulated by synthetically added $\mathrm{NaNO}_{2}\left(30 \mathrm{~g}\right.$ of N/L), $\mathrm{NH}_{4} \mathrm{Cl}(24 \mathrm{~g}$ of N/L), and reject water, respectively. The latter contained $\mathrm{NH}_{4}{ }^{+}-\mathrm{N}(1400 \mathrm{mg}$ of N/L) and the appropriate composition of trace elements and minerals [26]. Before start-up, the mixed sludge was diluted using tap water to achieve an initial $\mathrm{NH}_{4}{ }^{+}-\mathrm{N}$ concentration of $220 \mathrm{mg}$ of N/L. During further operation, the summary $\mathrm{NO}_{2}{ }^{-}$and $\mathrm{NH}_{4}{ }^{+}$concentration of the influent 
was around $100-150 \mathrm{mg}$ of $\mathrm{N} / \mathrm{L}$ to imitate the TN concentration present in mainstream wastewater.

Samples were collected every 2-3 days. The TN concentration in the effluent and influent mixture was analyzed in $\mathrm{mg}$ of $\mathrm{N} / \mathrm{L}$ concentration of $\mathrm{NO}_{3}{ }^{-}, \mathrm{NO}_{2}{ }^{-}$, and $\mathrm{NH}_{4}{ }^{+}$ from the bioreactor three times per week, together with $\mathrm{pH}$ and temperature monitoring.

Nitrogen forms' concentrations were analyzed in both the influent and effluent samples after water sample centrifuging at $4500 \mathrm{rpm}$.

\subsection{Batch Testing}

Batch testing was conducted to assess the effect of hydrazine spiking with different concentrations of $\mathrm{N}_{2} \mathrm{H}_{4}$ (hydrazine) at 2, 2.5, 5, 7.5, 10, and $12.5 \mathrm{mg} / \mathrm{L}$ on SAA. In order to study the combined effect of organic carbon and hydrazine, sodium acetate was added at a concentration of COD $1000 \mathrm{mg} / \mathrm{L}$ into the batch test with $7.5 \mathrm{mg}$ of $\mathrm{N}_{2} \mathrm{H}_{4} / \mathrm{L} . \mathrm{NO}_{2}{ }^{-}-\mathrm{N}$ and $\mathrm{NH}_{4}{ }^{+}-\mathrm{N}$ were added into all tests at concentrations of $20-40 \mathrm{mg}$ of $\mathrm{NO}_{2}{ }^{-}-\mathrm{N} / \mathrm{L}$ and $40-70 \mathrm{mg}$ of $\mathrm{NH}_{4}{ }^{+}-\mathrm{N} / \mathrm{L}$, respectively. Tests were done at a temperature of $30^{\circ} \mathrm{C}$ in a $20 \mathrm{~L}$ reactor measuring nitrogen compounds after every $2 \mathrm{~h}$ during the $6 \mathrm{~h}$ period. Tests with the same biomass without added hydrazine were done on the same day as the control to rule out biomass activity changes during reactor operation days. TN concentration was analyzed in mg N/L of summary $\mathrm{NO}_{3}{ }^{-}, \mathrm{NO}_{2}{ }^{-}$, and $\mathrm{NH}_{4}{ }^{+} . \mathrm{NO}_{2}{ }^{-}$and $\mathrm{NH}_{4}$ removal was also separately calculated as anammox-specific activity, and $\mathrm{NO}_{3}{ }^{-}$reduction was emphasized as denitrification activity.

\subsection{Chemical Analyses and Calculations}

A Metrohm 930 Compact IC Flex 1 chromatograph equipped with anion column Metrosep A Supp 5-100/4.0 was applied for nitrite/nitrate and salinity measurements with $1.0 \mathrm{mM}$ of $\mathrm{NaHCO}_{3}$ ja and $3.2 \mathrm{mM}$ of $\mathrm{Na}_{2} \mathrm{CO}_{3}$ solution used as the eluent. Hach Lange LCK 314 and LCK 514 COD cuvette tests were used for the determination of chemical oxygen demand (COD) according to the manufacturer's instructions, and the measurements were performed using a Hach Lange DR 2800 spectrophotometer. The same device was also used for the determination of ammonium and hydrazine. The former was carried out using the Nessler's colorimetric method (Hach Lange method 8038), and the latter using HydraVer ${ }^{\circledR}$ reagent (Hach Lange method 8141). Analytical grade hydrazine sulphate supplied by Merck was used as the hydrazine source. MLSS determination was done according to [27]. The Evikon E6115 pH meter was used for $\mathrm{pH}$ measurement. TNREs and TNRRs were calculated based on the feed flow rate, influent and effluent ammonium, nitrite, nitrate parameters, and the flow rate into the reactor according to the following equation:

$$
\begin{gathered}
\text { TNRE }=\frac{\left(\sum[N]_{\text {inf }}-\sum[N]_{\text {eff }}\right)}{\sum[N]_{\text {inf }}} \times 100 \\
\text { TNRR }=\frac{Q\left(\sum[N]_{\text {inf }}-\sum[N]_{\text {eff }}\right)}{\sum[N]_{\text {inf }}}
\end{gathered}
$$

where $Q$ was the daily loading rate, $\mathrm{g} \mathrm{N} \mathrm{m}^{3} \mathrm{~d}^{-1}, \Sigma[\mathrm{N}]_{\text {inf }}$, and $\sum[\mathrm{N}]_{\text {eff }}$ were the sums of the inorganic nitrogen species $\left(\mathrm{NO}_{2}{ }^{-}-\mathrm{N}, \mathrm{NO}_{3}{ }^{-} \mathrm{N}\right.$, and $\left.\mathrm{NH}_{4}{ }^{+}-\mathrm{N}\right)$ in the influent and effluent, respectively ( $\mathrm{g}$ of $\mathrm{N} / \mathrm{L})$.

To calculate SAA, linear regression of nitrogen species concentrations' decrease was taken, and the value was divided with measured MLSS concentration $(\mathrm{g} / \mathrm{L})$ and time $(\mathrm{h})$.

For statistics, two-tailed Pearson correlation was done to assess the correlation between parameters. Additionally, Student's $t$-tests were done using the Excel statistics Tool pack. The significance level between tests was set at $p<0.05$. 


\section{Results}

\subsection{Bioreactor Performance and Division into Three Phases}

During the start-up of SBR, inoculum based on nitrification-denitrification and anaerobic sludge was cultivated as an autotrophic nitrogen removal performing biomass. The analysis of the TNRR and TNRE of the anammox process in the overall start-up process was divided into three phases. The first period was microbial the acclimatization/activation phase, with only nitrite feeding in the form of $\mathrm{NaNO}_{2}$. It was done due to the fact that ammonium was still present from the inoculation sludge. This was the reason why the phase had characteristically low salinity $\left(<0.2 \mathrm{~g} \mathrm{Cl}^{-} / \mathrm{L}\right)$. Low salinity values and the decrease in organic content enabled the activation of the autotrophic ammonium oxidation process. The second phase was the high salinity phase $\left(18.2 \mathrm{~g} \mathrm{Cl}^{-} / \mathrm{L}\right)$, which involved the addition of $\mathrm{NH}_{4} \mathrm{Cl}$ and $\mathrm{NaNO}_{2}$ as nitrogen and salinity sources. Salinity increased due to the addition of $\mathrm{NH}_{4} \mathrm{Cl}$ and $\mathrm{NaNO}_{2}$, enabling $\mathrm{Cl}^{-}$and $\mathrm{Na}^{+}$to increase salinity values significantly. The third phase followed the addition of reject water and $\mathrm{NaNO}_{2}$, characteristic of an optimum salinity phase $\left(0.5-2 \mathrm{~g} \mathrm{Cl}^{-} / \mathrm{L}\right)$. The salinity drop was regulated by discontinuing the $\mathrm{NH}_{4} \mathrm{Cl}$ supply.

The initial $\mathrm{NH}_{4}{ }^{+}-\mathrm{N}$ concentration in the SBR was $220 \mathrm{mg}$ of $\mathrm{N} / \mathrm{L}$, followed by a subsequent addition of $\mathrm{NH}_{4} \mathrm{Cl}, \mathrm{NaNO}_{2}$, and reject water as $\mathrm{N}$ sources during the operation period.

The bioreactor achieved approximately $80 \%$ of the average TNRE after 110 days of start-up (Figure 1) due to optimum conditions achieved for the process of optimum salinity and due to the organic carbon being consumed.

The TNLR at day 0 was at $0.012 \mathrm{~kg} \mathrm{~N} / \mathrm{m}^{3} / \mathrm{d}$, and it increased to $0.1 \mathrm{~kg} \mathrm{~N} / \mathrm{m}^{3} / \mathrm{d}$ at the end of the operation of the reactor. Respective TNRRs recorded were 0 and 0.08 and $\mathrm{kg}$ $\mathrm{N} / \mathrm{m}^{3} / \mathrm{d}$.

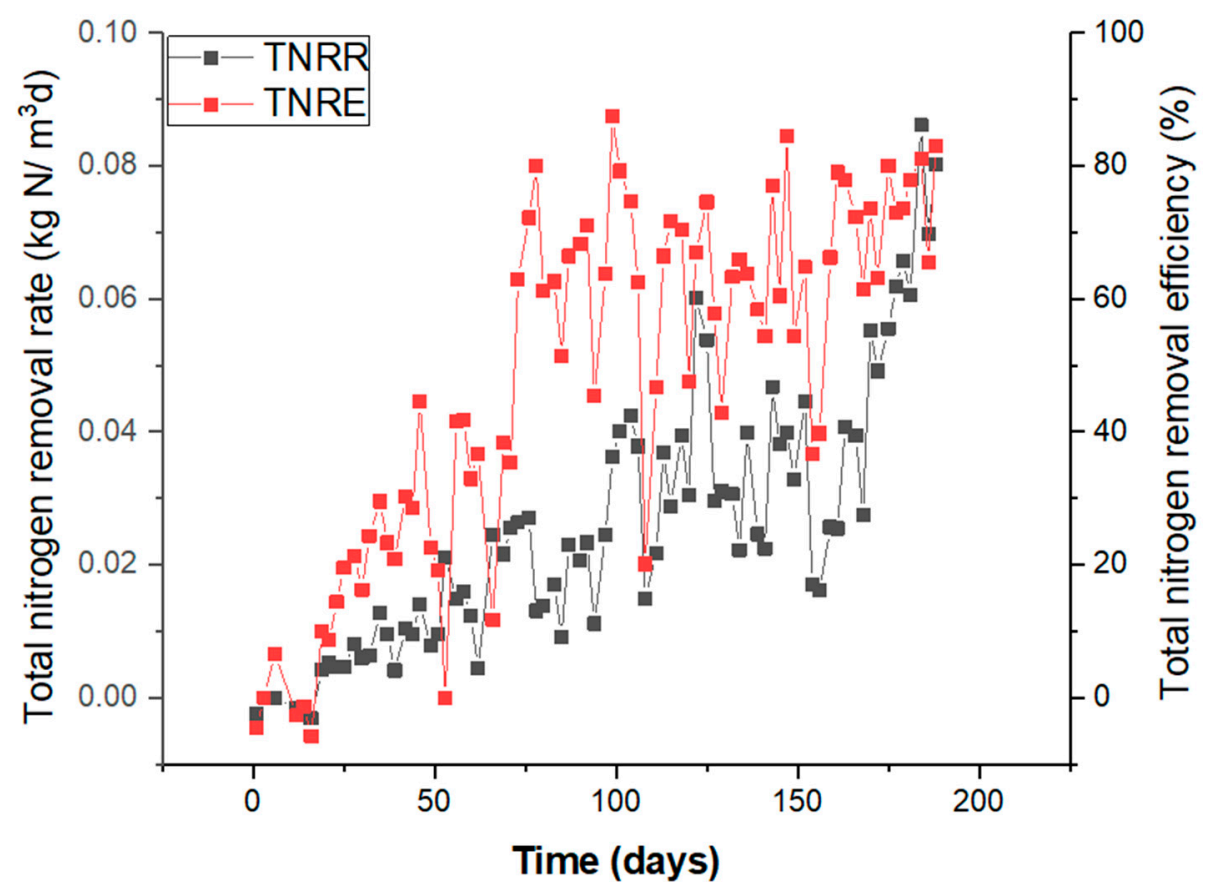

Figure 1. Overall performance of the reactor based on the TNRR and TNRE within 194 days of start-up.

When the feed COD/TN ratio was below 1/1, the conditions suitable for anammox bacteria propagation were seen. There was only a minimal concentration of external organic carbon compounds in the bioreactor (COD $<180 \mathrm{mg} / \mathrm{L}$ ), coming from the inoculation biomass and reject water. The autotrophic nature of the biomass after 110 days was confirmed by near-anammox stoichiometric ammonium and nitrite consumption (1/1.32), 
nitrate accumulation into the effluent, and COD values being unchanged between the influent and effluent.

\subsection{Adaptation/Activation Phase}

The adaptation/activation phase lasted for 65 days, and was considered as a low salinity phase $\left(<0.2 \mathrm{~g} \mathrm{Cl}^{-} / \mathrm{L}\right)$. $\mathrm{NO}_{2}{ }^{-}, \mathrm{NH}_{4}{ }^{+}$, and organic compounds coming from the inoculum were the major substrates present in the reactor. The comparison of the influent and effluent $\mathrm{NH}_{4}{ }^{+}-\mathrm{N}$ concentration indicated an increase in the effluent $\mathrm{NH}_{4}-\mathrm{N}$ in the bioreactor, while the influent $\mathrm{NO}_{2}{ }^{-}-\mathrm{N}$ decreased considerably well compared to the effluent (Figure 2a-c). The increase in $\mathrm{NH}_{4}{ }^{+}-\mathrm{N}$ was caused by the cell autolysis and the decay of dead cells anaerobically degraded to organic substances. The increase in $\mathrm{NH}_{4}{ }^{+}-\mathrm{N}$ could also be due to the DNRA process performance, reducing nitrate into nitrite and thereafter into $\mathrm{NH}_{4}{ }^{+}-\mathrm{N}$ by the aid of organic carbon. Anammox bacteria could occur together with organisms mediating dissimilatory nitrate reduction to ammonium (DNRA), proven by the decrease of nitrate and nitrite at the initial stage [28,29]. Some of the $\mathrm{NO}_{2}{ }^{-}-\mathrm{N}$ losses observed in this phase could be occurring because of denitrifying bacteria. The dissolved organic material produced within this period served as substrate for denitrifiers, with a concomitant consumption of $\mathrm{NO}_{2}{ }^{-}-\mathrm{N}$.

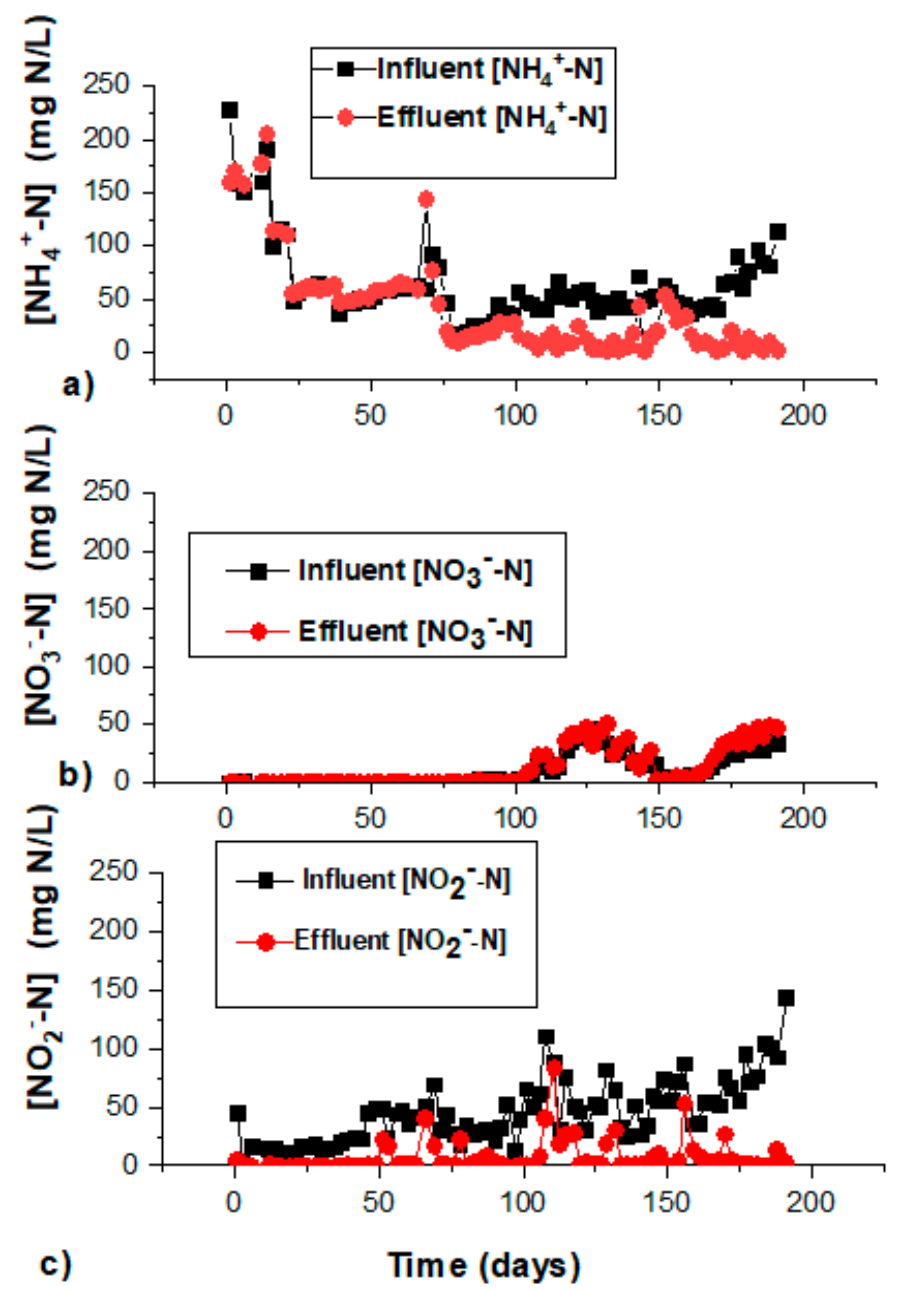

Figure 2. The time courses of (a) $\mathrm{NH}_{4}{ }^{+}$in the influent and effluent within the start-up period; (b) $\mathrm{NO}_{3}{ }^{-}$in the influent and effluent within the start-up period; and (c) $\mathrm{NO}_{2}{ }^{-}$in the influent and effluent within the start-up period.

Batch testing on day 31 and day 60 revealed the production of $\mathrm{NO}_{3}{ }^{-}-\mathrm{N}$, but the daily effluent result showed the absence of $\mathrm{NO}_{3}{ }^{-}-\mathrm{N}$ within this phase, which evidently reveals 
the presence and activity of denitrifiers. At the end of the stagnation phase, an increase in the TNRR and $\mathrm{NH}_{4}{ }^{+}-\mathrm{N}$ consumption was present to indicate anammox activity.

In the first phase of operation, the biomass concentration measured in the MLSS decreased from $10.8( \pm 0.25)$ to $9.00( \pm 0.05)$ from day 1 to day 10 , and further to $8.10( \pm 0.35) \mathrm{g} / \mathrm{L}$ on day 31 . This decrease is connected to the adaptation incapacity occasioned by changes in the environmental condition with no external organic carbon feeding during inoculation.

The TNRE within this low salinity period was within the range 20\% to $40 \%$ (Figure 1). The estimation of the total nitrogen (TN) concentration removed in the stagnation phase was contributed by $\mathrm{NO}_{2}{ }^{-}-\mathrm{N}$ and $\mathrm{NO}_{3}{ }^{-}-\mathrm{N}$ reduction (Figure $2 \mathrm{~b}, \mathrm{c}$ ), while the decrease in the ammonium concentration was not noticed at the beginning, contributed majorly by the assimilation of nitrogen from decayed bacteria. $\mathrm{NO}_{2}{ }^{-}-\mathrm{N}$ and $\mathrm{NO}_{3}{ }^{-}-\mathrm{N}$ reduction at the beginning was probably due to the denitrification process still being active. Denitrifying activity could have been happening until organic carbon released from the initial nitrifyingdenitrifying biomass was totally consumed. Thereafter, slow-growing anammox bacteria would not have to compete with denitrifiers for nitrite as the electron acceptor. In the anammox reaction, the utilization of one mole of $\mathrm{NO}_{2}{ }^{-}-\mathrm{N}$ requires 1.32 moles of $\mathrm{NO}_{2}{ }^{-} \mathrm{N}$, with the concomitant release of 0.26 moles of $\mathrm{NO}_{3}{ }^{-}-\mathrm{N}^{-} \mathrm{NH}_{4}{ }^{+}-\mathrm{N}$ removal was considerably low compared to the summary $\mathrm{NO}_{3}{ }^{-}-\mathrm{N}$ and $\mathrm{NO}_{2}{ }^{-}-\mathrm{N}$ removal (Figure $2 \mathrm{~b}, \mathrm{c}$ ), giving the ratio of $\mathrm{NO}_{2}{ }^{-}-\mathrm{N} / \mathrm{NH}_{4}{ }^{+}-\mathrm{N}$ of $2.52( \pm 0.51) / 1$, showing that denitrification dominated over anaerobic ammonium oxidation, but aerobic nitrite oxidation was controlled at low levels in this period.

\subsection{High Salinity Phase}

In this phase, anammox activity was seen with a concomitant decrease in $\mathrm{NO}_{2}{ }^{-} \mathrm{N}$ and $\mathrm{NH}_{4}{ }^{+}-\mathrm{N}$ concentrations in the effluent, despite high salinity represented in the SBR. In this phase, synthetic $\mathrm{NH}_{4}{ }^{+} \mathrm{N}$ was used as the ammonium source in the form of $\mathrm{NH}_{4} \mathrm{Cl}$, while $\mathrm{NO}_{2}{ }^{-}-\mathrm{N}$ was introduced in the form of $\mathrm{NaNO}_{2}$, which led to an increase in the salinity of the bioreactor at 10-18 $\mathrm{g}$ of $\mathrm{Cl}^{-} / \mathrm{L}$. This phase lasted for $65-110$ days (Figure 1 ). TNRRs achieved were up to $0.05 \mathrm{~kg} \mathrm{~N} / \mathrm{m}^{3} / \mathrm{d}$ and TNREs achieved were up to $67-87 \%$. The MLSS measured was $7.10( \pm 0.82) \mathrm{g} / \mathrm{L}$.

Salinity at a concentration within the range of 3-15 $\mathrm{g}$ of $\mathrm{NaCl} / \mathrm{L}$ facilitates better retention of the biomass and the formation of anammox granular sludge [30], and possibly negatively affects denitrifier activity. The choice of the salinity increase was based on the previous finding that $6-10 \mathrm{~g}$ of $\mathrm{NaCl} / \mathrm{L}$ has shown a stimulatory effect on $\mathrm{AOBs}$ and anammox activity, while at a higher salinity $(30 \mathrm{~g}$ of $\mathrm{NaCl} / \mathrm{L})$, there has been a decrease in anammox performance $[15,30,31]$. At $30 \mathrm{~g}$ of $\mathrm{NaCl} / \mathrm{L}$, both anammox and $\mathrm{AOB}$ activity decreased $95 \%$ and $43 \%$ for the non-salt adapted biomass, respectively, while for the saltadapted biomass, the decrease was only $59 \%$ and $24 \%$, respectively [15]. In our case, the TNRR decreased for $\sim 30 \%$ at the high salinity period compared with the optimum salinity phase TNRR results.

The ratio of $\mathrm{NO}_{2}{ }^{-}-\mathrm{N} / \mathrm{NH}_{4}{ }^{+}-\mathrm{N}$ in the effluent of the bioreactor was lower than 1.31/1, at an average of $1.03( \pm 0.16) / 1$ (Table 1$)$. This was indicative of slightly lowered activity of the anammox process due to the rapid increase in salinity. The utilization of nitrite for anammox activity was considerably lower compared to stoichiometric nitrite utilization. The effluent nitrate produced within this phase was low due to lowered activity of NOBs at high salinity. NOB activity at the high salinity phase was lower than at the optimum salinity phase (Figure 2b), in accordance with [15].

According to literature studies, it has been shown that Candidatus Kuenenia stuttgartiensis can acclimate to a high salt concentration of $90 \% \mathrm{NaCl}$ and $10 \% \mathrm{KCl}$ [32]. The inhibitory effect of high salt concentration on the activity of the anammox biomass is reversible. As most of the anammox bacteria thrive in freshwater environments and Brocadia anammoxidans could tolerate low salinity, lower salinity concentrations were suitable for the anammox process $[15,16]$. 
Table 1. The conversion ratio based on the mass balance $\mathrm{NO}_{2}{ }^{-}-\mathrm{N} / \mathrm{NH}_{4}{ }^{+}-\mathrm{N}$ within the start-up period.

\begin{tabular}{cc}
\hline Start-Up Period (Days) & $\mathbf{N O}_{2}{ }^{-}-\mathbf{N} / \mathbf{N H}_{\mathbf{4}}{ }^{+} \mathbf{- N}$ \\
\hline $66-99$ & $2.52( \pm 0.51) / 1$ \\
$101-125$ & $1.03( \pm 0.16) / 1$ \\
$126-145$ & $1.12( \pm 0.12) / 1$ \\
$146-194$ & $1.33( \pm 0.06) / 1$ \\
\hline
\end{tabular}

\subsection{Optimum Salinity Phase}

It became evident that during 110-194 days of operation, the optimum conditions for an efficient nitrogen removal process were achieved. In this phase, it was shown that there was complete depletion of organic carbon from cell autolysis that had supported the activity of denitrifiers at the first stage of operation. The synergy between denitrifiers and anammox and the possible competition of both groups of microorganisms for nitrite was noticeable in the high salinity phase, resulting in higher anammox activity from 110 days onwards (Figure 2c). The salinity was below $0.5 \mathrm{~g} \mathrm{of} \mathrm{Cl}^{-} / \mathrm{L}$ in this phase, brought down from $18.2 \mathrm{~g}$ of $\mathrm{Cl}^{-} / \mathrm{L}$ present in the previous stage. The performance of the bioreactor in this phase of optimum salinity was achieved by the discontinuance of $\mathrm{NH}_{4} \mathrm{Cl}$ addition and the use of reject water. The influent concentration of $\mathrm{NO}_{2}{ }^{-}-\mathrm{N}$ and $\mathrm{NH}_{4}{ }^{+}-\mathrm{N}$ added was increased according to the performance of the bioreactor. The TNRE of 87\% (Figure 1) was achieved for the reactor stabilized at a temperature of $30^{\circ} \mathrm{C}$ and at a $\mathrm{pH}$ of $7.5-8.3$. The TNRR rose to approximately $0.08 \mathrm{~kg} \mathrm{~N} / \mathrm{m}^{3} / \mathrm{d}$ within this period at optimum salinity, compared to other phases. The MLSS measured was $6.73( \pm 0.23) \mathrm{g} / \mathrm{L}$.

The ratio of $\mathrm{NO}_{2}{ }^{-}-\mathrm{N} / \mathrm{NH}_{4}{ }^{+}-\mathrm{N}$ was at $1.12( \pm 0.12) / 1$ during days $126-145$. The ratio of $\mathrm{NO}_{2}{ }^{-}-\mathrm{N} / \mathrm{NH}_{4}{ }^{+}-\mathrm{N}$ was shifted within further operation at an average of $1.33( \pm 0.06) / 1$ on days 146-193, which was indicative that the bioreactor achieved full anammox activity according to [7]. In this phase, the effluent nitrate increased in direct relation to the amount of $\mathrm{NO}_{2}{ }^{-}-\mathrm{N}$ that was consumed. This phenomenon leads to a higher amount of $\mathrm{NO}_{3}{ }^{-} \mathrm{N}$ observed in the effluent compared to the influent $\mathrm{NO}_{3}{ }^{-}-\mathrm{N}$ (Figure $2 \mathrm{~b}$ ). A build-up of nitrate in the reactor is indicative of a complete anammox process.

Previous studies have highlighted the prevalence of the denitrification process occurring simultaneously in nutrient removal systems, which can lead to nitrate reduction [2,26]. The use of low molecular weight organic acids by anammox bacteria as the electron donor to favor an organotrophic anammox process rather than an autotrophic anammox process has also been mentioned for certain groups of anammox bacteria [33]. Anammox bacteria has also been linked to organisms mediating a dissimilatory nitrate reduction to ammonium (DNRA); this process accounts for the partial loss of nitrate under an anoxic condition [28]. The possible competition for the utilization of organic carbon at a low $\mathrm{C} / \mathrm{N}$ ratio $(<1 / 5)$ released from the DNRA process by Candidatus Brocadia sinica over denitrifiers has also been reported in previous work [29]. Accounting for some of the $\mathrm{NO}_{3}{ }^{-}-\mathrm{N}$ losses observed in this phase, these losses can be traceable to partial DNRA activity by anammox bacteria and partial denitrification by denitrifying bacteria.

Previous studies have highlighted the successful start-up using different inocula. The start-up has been achieved at a low temperature using UASB and a membrane bioreactor $[11,33]$. Using conventional activated sludge in SBR, the start-up of the anammox process was achieved within 110 days at $30^{\circ} \mathrm{C}$ [34].

Table 2 shows the comparison of the TNRRs achieved during the start-up of the anammox process for different reactors available in the literature and one from the current study. These reactors were operated under different conditions, including the temperature, type of sludge, and reactor configuration. The time taken to achieve the start-up of the anammox process, the efficiency, and the TNRR differ in relation to different contributing factors. The start-up has been achieved at a low temperature $\left(10-20^{\circ} \mathrm{C}\right)$ using an SBR/membrane bioreactor system to reach a TNRR of $0.027 \mathrm{~kg} \mathrm{~N} / \mathrm{m}^{3} / \mathrm{d}$, while that for a gas-lift reactor was $0.29 \mathrm{~kg} \mathrm{~N} / \mathrm{m}^{3} / \mathrm{d}[35,36]$. Hu et al. (2013) achieved a start-up using a partial nitration anam- 
mox process in an SBR at $30{ }^{\circ} \mathrm{C}$, and reached a nitrogen removal rate of $0.028 \mathrm{~kg} \mathrm{~N} / \mathrm{m}^{3} / \mathrm{d}$, lower than that achieved in the current study $\left(0.08 \mathrm{~kg} \mathrm{~N} / \mathrm{m}^{3} / \mathrm{d}\right)[4]$.

Table 2. Comparison of anammox removal rates by different sludge and reactor types.

\begin{tabular}{|c|c|c|c|c|c|c|c|}
\hline $\begin{array}{l}\text { Bioreactor } \\
\text { Type }\end{array}$ & Temp. $\left({ }^{\circ} \mathrm{C}\right)$ & $\begin{array}{c}\text { Start-Up } \\
\text { Time (Days) }\end{array}$ & $\begin{array}{l}\text { Volume of } \\
\text { Reactor (L) }\end{array}$ & $\begin{array}{l}\text { TNRR (kg } \\
\left.\text { N/m } / \mathrm{m}^{3} / \mathrm{d}\right)\end{array}$ & $\begin{array}{l}\text { Include } \\
\text { Nitration }\end{array}$ & Sludge Type & Author \\
\hline SBR/MBR & 10 & 727 & 4.2 & 0.027 & - & $\begin{array}{l}\text { Mixed } \\
\text { activated } \\
\text { sludge }\end{array}$ & [36] \\
\hline SBR & 30 & 345 & 5 & 0.028 & + & Start-up & {$[4]$} \\
\hline RBC & 29 & 300 & 2.5 & 0.60 & + & Start-up & [37] \\
\hline $\begin{array}{l}\text { Gas-lift } \\
\text { reactor }\end{array}$ & 20 & 253 & 4.5 & 0.29 & - & $\begin{array}{c}\text { Anammox } \\
\text { sludge }\end{array}$ & [35] \\
\hline MBR & 35 & 110 & 4.8 & 0.159 & + & $\begin{array}{l}\text { Conventional } \\
\text { activated } \\
\text { sludge }\end{array}$ & [34] \\
\hline SBR & 30 & 193 & 20 & 0.127 & - & $\begin{array}{l}\text { Start-up with } \\
\text { activated and } \\
\text { anaerobic } \\
\text { sludge }\end{array}$ & $\begin{array}{c}\text { Current } \\
\text { study }\end{array}$ \\
\hline
\end{tabular}

\subsection{Batch Cycle Analysis}

To evaluate the acceleration of anammox biomass specific activity and maintain low denitrifying activity during start-up, SAA tests were performed. SAAs during the reactor operation period were measured within a period 31-149 days (Figure 3). SAAs were shown as: SAA (TN), indicating ammonium, nitrite, and nitrate summary consumption by anammox and denitrifiers; SAA $\left(\mathrm{NH}_{4}{ }^{+}+\mathrm{NO}_{2}{ }^{-}\right)$, showing anammox-characteristic nitrite and ammonium removal; and SAA $\left(\mathrm{NO}_{2}{ }^{-}+\mathrm{NO}_{3}{ }^{-}\right)$, showing nitrate and nitrate reduction, emphasizing denitrifying microorganisms' role. Batch tests were carried out in the reactor during the first 100 days of start-up without the addition of hydrazine and a further 49 days with hydrazine addition (Figure 3). The first 100 days represent the adaptation phase of the anammox bacteria. During this period, a low SAA $\left(\mathrm{NH}_{4}{ }^{+}+\mathrm{NO}_{2}{ }^{-}\right)$was noticed for the first 60 days of the anammox process start-up, ranging from $0.08( \pm 0.05) \mathrm{mg} \mathrm{N} / \mathrm{g}$ MLSS $/ \mathrm{h}$ to $0.16( \pm 0.08) \mathrm{mg} \mathrm{N} / \mathrm{g}$ MLSS $/ \mathrm{h}$. The next 30 days of operation revealed an increase in the SAA $\left(\mathrm{NH}_{4}{ }^{+}+\mathrm{NO}_{2}{ }^{-}\right)$to $0.62( \pm 0.03) \mathrm{mg} \mathrm{N} / \mathrm{g}$ MLSS/h (Figure 3). SAA on $\left(\mathrm{NO}_{2}{ }^{-}+\right.$ $\mathrm{NO}_{3}{ }^{-}$) showed a decrease between 30 days and 60 days of operation batch tests, implying a reduction of denitrifying activity and an increase of anammox activity within the SBR (Figure 3). Thereafter, high salinity decreased the SAA to $0.3 \mathrm{mg} \mathrm{N} / \mathrm{g}$ MLSS/h, which was overcome on further operation (by day 121) at optimum salinity. The SAA (TN) increased within 100-121 days, staying between $0.4-1 \mathrm{mg} \mathrm{N} / \mathrm{g}$ MLSS $/ \mathrm{h}$.

When the SAA was decreased due to increased salinity (65-110 days), denitrification activity was also decreased in relation to the anammox activity, showing that the inhibitory effect of salinity on denitrification was relatively stronger than the effect on anammox.

The optimum hydrazine concentration to reach the highest SAA was also studied in a set of batch assays (Figure 4) to assess the hydrazine effect on the anammox process and its inhibitory effect on the denitrification process. The enhancement of anammox bacteria activity by hydrazine addition has shown a positive effect in batch cycles and reactor operation in earlier studies [19], but decreasing denitrifier activity by hydrazine would increase the possibilities in anammox systems development. The activity of anammox bacteria containing a biomass was monitored within a duration of $6 \mathrm{~h}$ of each batch test after spiking with different concentrations of anammox intermediate hydrazine, together with $\mathrm{NH}_{4}{ }^{+}$and $\mathrm{NO}_{2}{ }^{-}$. Furthermore, nitrate production and consumption were shown to be diminished by hydrazine addition (Figure 4). 


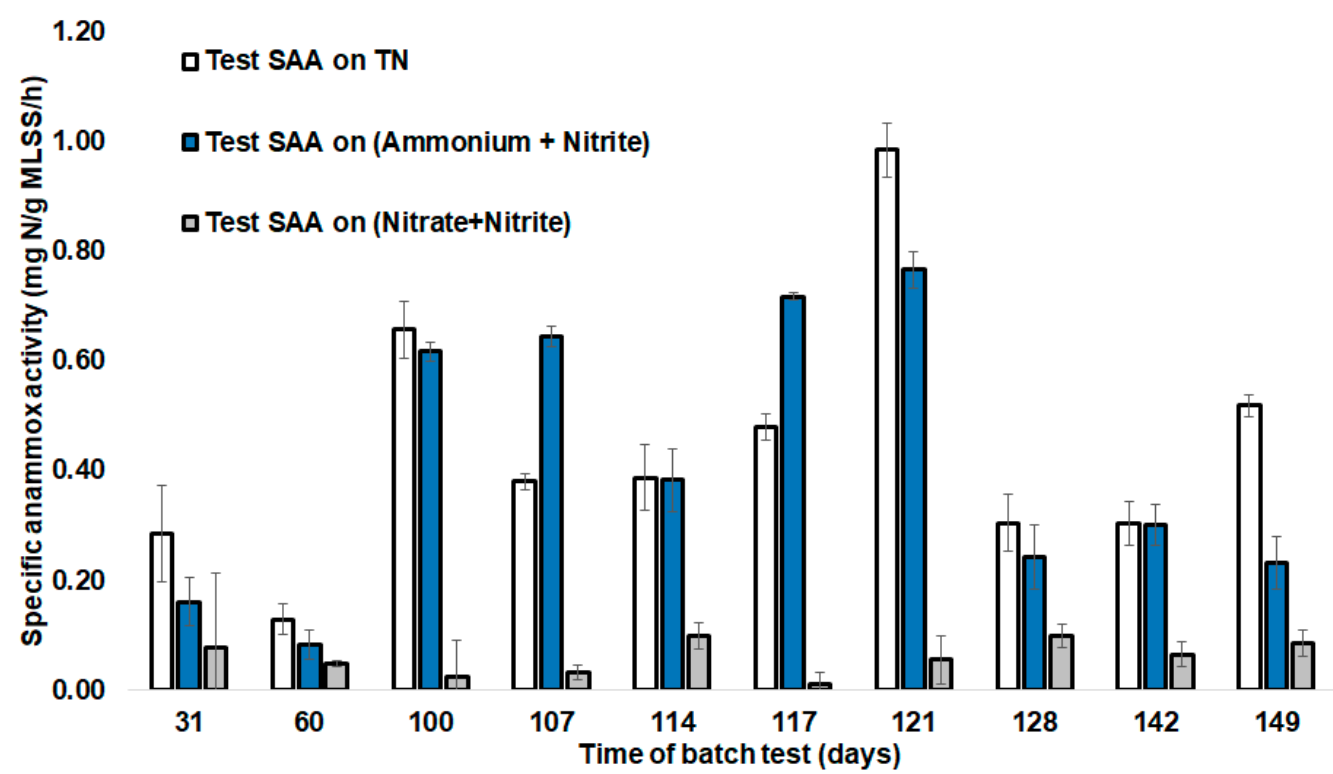

Figure 3. SAAs during batch testing in SBR operation days. Error bars represent the standard deviation between parallel batch tests $(n=3)$.

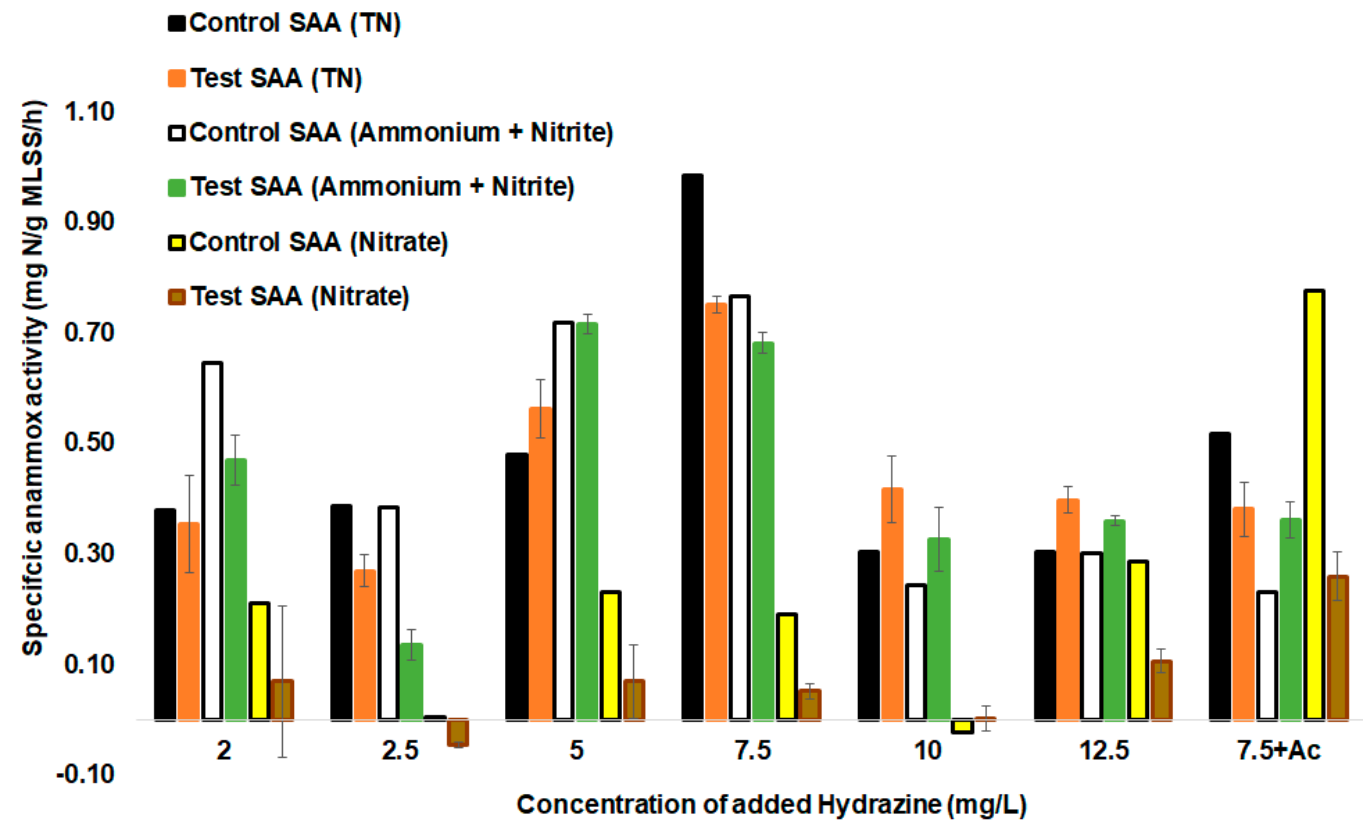

Figure 4. SAAs during batch testing after the addition of different concentrations of hydrazine, without the addition of hydrazine, and spiking with hydrazine and acetate (Ac). Error bars represent the standard deviation between parallel batch tests $(n=3)$.

The first of the batch cycle analyses involved the hydrazine effect assessment in the tests with hydrazine and control tests without the addition of hydrazine. The tests using $5 \mathrm{mg}$ of $\mathrm{N}_{2} \mathrm{H}_{4} / \mathrm{L}$ resulted in an SAA (TN) of $0.72( \pm 0.01) \mathrm{mg} \mathrm{N} / \mathrm{g}$ MLSS $/ \mathrm{h}$, while that for the control test was lower at $0.68( \pm 0.06) \mathrm{mg} \mathrm{N} / \mathrm{g}$ MLSS/h (Figure 4). Therefore, the addition of $5 \mathrm{mg}$ of $\mathrm{N}_{2} \mathrm{H}_{4} / \mathrm{L}$ significantly improved anammox activity when compared to the control test $(p$-value $<0.05)$. The highest SAAs $(\mathrm{TN})$ were achieved by using $7.5 \mathrm{mg}$ of $\mathrm{N}_{2} \mathrm{H}_{4} / \mathrm{L}$, resulting in an SAA $\left(\mathrm{NO}_{2}{ }^{-}+\mathrm{NH}_{4}{ }^{+}\right)$of $0.77( \pm 0.06) \mathrm{mg} \mathrm{N} / \mathrm{g}$ MLSS/h. Spiking with $10 \mathrm{mg} / \mathrm{L}$ and $12.5 \mathrm{mg} / \mathrm{L}$ of $\mathrm{N}_{2} \mathrm{H}_{4}$ showed lower values of SAAs at $0.33( \pm 0.1) \mathrm{mg}$ $\mathrm{N} / \mathrm{g}$ MLSS/h and $0.36( \pm 0.07) \mathrm{mg} \mathrm{N} / \mathrm{g}$ MLSS/h, respectively, lower than obtained for 5 and $7.5 \mathrm{mg}$ of $\mathrm{N}_{2} \mathrm{H}_{4} / \mathrm{L}$ (Figure 4). 
For low concentrations of hydrazine added ( 2 and $2.5 \mathrm{mg}$ of $\mathrm{N}_{2} \mathrm{H}_{4} / \mathrm{L}$ ), significant improvement in the SAA did not occur between the test and control, probably due to concentrations being too low to enhance anammox metabolism in this setup. Previous studies carried out using a control and a test bioreactor with hydrazine have shown that hydrazine addition did not significantly increase the SAA, but rather helped to achieve a shorter start-up time of seven weeks compared to that of the control, which took 11 weeks [21]. Ganesan and Vadivelu (2019) also highlighted that the external addition of hydrazine at $10 \mathrm{mg}$ of $\mathrm{N}_{2} \mathrm{H}_{4} / \mathrm{L}$ helped in the reduction of the anammox biomass startup time by $50 \%$ to achieve maximum removal of nitrite and ammonium after 49 days compared to sludge types, which used non-specific anammox inoculum for start-up [21]. There was a different outcome in the current study using a non-specific biomass, showing that the addition of $\mathrm{N}_{2} \mathrm{H}_{4}$ of 5,10 , and $12 \mathrm{mg}$ of $\mathrm{N}_{2} \mathrm{H}_{4} / \mathrm{L}$ and $7.5 \mathrm{mg}$ of $\mathrm{N}_{2} \mathrm{H}_{4} / \mathrm{L}$ together with acetate significantly improved the anammox SAA (ammonium and nitrite) in a test compared to the control test.

External $\mathrm{N}_{2} \mathrm{H}_{4}$ provides an easily biodegradable substrate to be metabolized by the anammox bacteria. The effect of $\mathrm{N}_{2} \mathrm{H}_{4}$ in accelerating the SAA and start-up can be explained in two ways. Firstly, the metabolism is altered by the externally added $\mathrm{N}_{2} \mathrm{H}_{4}$ through a reaction step by the anammox bacteria in their anammoxosome, providing an additional energy source to carry out the nitrogen removal process [22]. Secondly, the availability of the extra energy sources drives the growth, repair, and storage of nutrients within the cell; the stored nutrients within the cell in the form of glycogen are deployed during stress and starvation to generate an energy and carbon source for bacteria.

A high concentration of $\mathrm{N}_{2} \mathrm{H}_{4}$ (concentrations greater than $10 \mathrm{mg}$ of $\mathrm{N}_{2} \mathrm{H}_{4} / \mathrm{L}$ ) has been linked to inhibiting anammox activity [38]. Different sources define hydrazine inhibition level differently, starting from $10 \mathrm{mg}$ of $\mathrm{N}_{2} \mathrm{H}_{4} / \mathrm{L}$ [38] or at $20 \mathrm{mg}$ of $\mathrm{N}_{2} \mathrm{H}_{4} / \mathrm{L}$ [23]. In our case, for added $\mathrm{N}_{2} \mathrm{H}_{4}$ concentrations of $12.5 \mathrm{mg}$ of $\mathrm{N}_{2} \mathrm{H}_{4} / \mathrm{L}$, the summary removal of ammonium and nitrite showed a value of $0.36( \pm 0.07) \mathrm{mg} \mathrm{N} / \mathrm{g}$ MLSS/h, whereas it was 0.3 $( \pm 0.04) \mathrm{mg} \mathrm{N} / \mathrm{g}$ MLSS/h for the control test, providing evidence that increased anammox activity even at $12.5 \mathrm{mg}$ of $\mathrm{N}_{2} \mathrm{H}_{4} / \mathrm{L}$ of hydrazine content is still possible. It can therefore be remarked that spiking with higher concentrations of $\mathrm{N}_{2} \mathrm{H}_{4}$ (over $10 \mathrm{mg} / \mathrm{L}$ ) can still increase the SAA (Figure 4). However, lower hydrazine concentrations also effectively acting in anammox systems in the SAA increase would benefit in the savings of hydrazine additions in the treatment system.

Different added hydrazine concentrations mostly decreased denitrification activity (Figure 4). In most cases, the test SAAs (nitrate) were lower than in the control tests. Denitrifying activity decreased 2-3 times in comparison with the control test. Hydrazine addition most strongly inhibited denitrifier activity in the batch tests at concentrations of 2, $5,7.5$, and $12.5 \mathrm{mg}$ of $\mathrm{N}_{2} \mathrm{H}_{4} / \mathrm{L}$. A steady decrease in the rate of nitrate reduction from 0.29 $( \pm 0.1) \mathrm{mg} \mathrm{N} / \mathrm{g}$ MLSS $/ \mathrm{h}$ for the control test to $0.11( \pm 0.05) \mathrm{mg} \mathrm{N} / \mathrm{g}$ MLSS/h for the test with hydrazine addition at a concentration of $12.5 \mathrm{mg}$ of $\mathrm{N}_{2} \mathrm{H}_{4} / \mathrm{L}$ was present. For some tests with hydrazine addition (with $2.5 \mathrm{mg}$ of $\mathrm{N}_{2} \mathrm{H}_{4} / \mathrm{L}$ ), nitrate reduction values dropped to negative values due to surplus nitrate produced by anammox bacteria. On the other hand, the rate of summary removal of ammonium and nitrite showed an opposite, increasing trend, along with an increase in the hydrazine content used. Thus, hydrazine contributed to a higher autotrophic nitrogen removal, both by boosting anammox activity and decreasing the activity of denitrifiers. Reduction in denitrification efficiency is needed in anammox systems, as denitrifiers compete with anammox bacteria for nitrite. The main implication of these tests for full-scale anammox reactors is that hydrazine increases autotrophic nitrogen removal efficiency in different ways, named above. Nevertheless, at least in the case of some denitrifiers, the inhibition seems to be transient, and bacteria show adaptability to hydrazine, accounting for the removal of some nitrate and nitrite in the mixed consortia during the reactor operation.

Batch test spiking with the addition of acetate (Ac) and $7.5 \mathrm{mg}$ of $\mathrm{N}_{2} \mathrm{H}_{4} / \mathrm{L}$ and the addition of acetate (Ac) (control) to increase the $\mathrm{C} / \mathrm{N}$ ratio to $10 / 1$ was also carried out 
(Figure 4). This test was done to see if hydrazine would enhance anammox activity in the conditions of a high $\mathrm{C} / \mathrm{N}$ ratio. The SAA (on $\mathrm{TN}$ ) showed a higher removal of ammonium, nitrite, and nitrate for the control over the hydrazine + Ac test. It showed that the denitrification rate was cut down by hydrazine addition. Similarly, it was proven by the SAA that nitrite and ammonium were higher for the hydrazine + Ac test than in the control test $(\mathrm{Ac})$. Latter SAAs $\left(\mathrm{NH}_{4}-\mathrm{N}+\mathrm{NO}_{2}-\mathrm{N}\right)$ for the control and the test were 0.2 and $0.36 \mathrm{mg} \mathrm{N} / \mathrm{g}$ MLSS $/ \mathrm{h}$, respectively. A high $\mathrm{C} / \mathrm{N}$ ratio led to a decline of anammox activity (SAAs $\left(\mathrm{NH}_{4}-\mathrm{N}+\mathrm{NO}_{2}-\mathrm{N}\right)$ ) compared to the test done with $7.5 \mathrm{mg} / \mathrm{L}$ of $\mathrm{N}_{2} \mathrm{H}_{4}$ and added organic carbon. The concomitant increase in the activity of denitrifiers' nitrate reduction rate in the control test with organic carbon was high at $0.78 \mathrm{mg} \mathrm{N} / \mathrm{g}$ MLSS $/ \mathrm{h}$, while the activity was significantly lower in the test with organic carbon $+7.5 \mathrm{mg} / \mathrm{L}$ of $\mathrm{N}_{2} \mathrm{H}_{4}$ added $(0.2( \pm 0.1) \mathrm{mg} \mathrm{N} / \mathrm{g}$ MLSS $/ \mathrm{h})$. This result showed that the external addition of $\mathrm{N}_{2} \mathrm{H}_{4}$ can help in achieving stable anammox activity and recovery from denitrifier overgrowth. A higher acetate concentration may also ameliorate high hydrazine concentration toxicity to denitrifiers, which needs to be studied further.

The hydrazine effect on increasing TNRR was observed in this study after the inhibition by a high $\mathrm{C} / \mathrm{N}$ ratio. There have also been earlier reports of the positive effect of $\mathrm{N}_{2} \mathrm{H}_{4}$ on accelerating TNRR and overcoming substrate inhibition [19,39]. The short-term addition of $\mathrm{N}_{2} \mathrm{H}_{4}$ on day 149 for seven days significantly led to a boost in anammox utilization of the substrate, with an over 100\% increase in the TNRR and TNLR at $0.1 \mathrm{~kg} \mathrm{~N} / \mathrm{m}^{3} / \mathrm{d}$ and $0.127 \mathrm{~kg} \mathrm{~N} / \mathrm{m}^{3} / \mathrm{d}$, respectively (Figure 1 ).

Nitrate accumulation resulting from high activity of NOB causes diminished anammox activity due to the unavailability of nitrite as a substrate consumed by NOB. The stoichiometry of nitrate produced during the anammox process is $0.26 \mathrm{~mol} \mathrm{NO}_{3}{ }^{-}-\mathrm{N}_{\text {pro- }}$ duced/mol of $\mathrm{NH}_{4}{ }^{+}-\mathrm{N}$ oxidized [7,40]. It was observed during the batch cycle tests that spiking with $\mathrm{N}_{2} \mathrm{H}_{4}$ led to an occurrence of a stepwise nitrate reduction before the end of the batch tests, indicating a possible deactivation of denitrifying and partial DNRA activity [28]. This trend can be indicative of hydrazine's ability to de-stimulate pathways that will result in the utilization of nitrate for other metabolic purposes. Xiao et al. (2015) highlighted that the long-term addition of trace hydrazine improved the performance of nitrogen removal [41], and had a strong inhibitory effect on NOBs in a bioreactor with an $\mathrm{NO}_{3}{ }^{-}-\mathrm{N} / \mathrm{NH}_{4}{ }^{+}-\mathrm{N}$ ratio lowering to less than that of the theoretical value [19]. $\mathrm{N}_{2} \mathrm{H}_{4}$ has been reported to inhibit the activity of NOBs by reducing the bacteria capacity to utilize nitrite in the formation of nitrate. It makes nitrite readily available for the anammox bacteria [41]. The inhibitory effect of hydrazine produced in situ by anammox bacteria on NOB activity has also been observed in [19]. The AOBs are less sensitive to hydrazine than NOBs, thus, nitrite production by AOBs is not affected detrimentally.

\subsection{Main Challenges for the Treatment of Real Wastewater by Anammox Process}

Overall, the main challenges for the treatment of real wastewater by the anammox process are connected with the full-scale implementation of the process from non-specific sludge and the methods for the cultivation of an anammox biomass. Setting up automation of the SBR system optimum hydrazine dosing is needed for applicability of the mainstream anammox process in a full scale, as hydrazine could enhance the anammox activity at the start-up phase, limiting denitrifier overgrowth and negative effects. The development and emergence of specific anammox bacteria can be accomplished by the aid of hydrazine addition in saline and non-saline conditions. Evaluation of the impact of low temperature on anammox biomass growth is needed for the development of microorganisms for the treatment of wastewater at low temperature (mainstream wastewater). Adaptation of bacteria with a high $\mathrm{C} / \mathrm{N}$ ratio to wastewater could drive simultaneous activity of anammox and denitrifiers, which eventually could cause inhibition to anammox bacteria. Optimal amounts of hydrazine added could compete with denitrifiers in such conditions. Microbial analysis at different stages of the start-up is needed for a more reliable process development based on optimum anammox bacteria quantities [42]. 


\section{Conclusions}

A simplified SBR setup was implemented at $30 \pm 0.5^{\circ} \mathrm{C}$ and operated for a period of 193 days. The start-up of the anammox process was achieved after 65 days of cultivation of the biomass. The treatment system design and operation in this study were successful, achieving a maximum TNRE of $87 \%$ and a maximum TNRR of $0.08 \mathrm{~kg} \mathrm{~N} / \mathrm{m}^{3} / \mathrm{d}$.

The system was started with a non-anammox-specific inoculum sludge, applying a hydraulic retention time (HRT) of 2-3 days during the operation period. Different salinity conditions were tested for anammox start-up. Reject water feeding gave the optimum salinity of $0.5-2 \mathrm{~g}$ of $\mathrm{Cl}^{-} / \mathrm{L}$, with a significantly higher nitrogen removal rate observed than in tests during the high salinity period $\left(18 \mathrm{~g}\right.$ of $\left.\mathrm{Cl}^{-} / \mathrm{L}\right)$. An average nitrogen removal efficiency of $80 \%$ was achieved at the optimum salinity period.

Spiking with different concentrations of anammox intermediate compound hydrazine was carried out. A hydrazine concentration of $5 \mathrm{mg}$ of $\mathrm{N}_{2} \mathrm{H}_{4} / \mathrm{L}$ indicated an SAA of 0.72 $( \pm 0.01) \mathrm{mg} \mathrm{N} / \mathrm{g}$ MLSS/d. Denitrifying activity was decreased in all tests when hydrazine was added compared with the control tests where hydrazine was not added. The addition of trace amounts of hydrazine short-term was able to enhance anammox activity after tests by a highly maintained $\mathrm{C} / \mathrm{N}$ ratio.

The start-up of the anammox process for a suspended biomass was successful, with hydrazine significantly accelerating anammox activity. The overall results showed an SBR operation with a non-specific inoculum and the application of an optimum concentration of hydrazine (5-12.5 mg of $\mathrm{N}_{2} \mathrm{H}_{4} / \mathrm{L}$ ) can effectively improve the start-up of the anammox process, giving higher SAAs and lowered denitrifying activities than without hydrazine addition.

Author Contributions: Conceptualization was done by I.Z. and K.O.; methodology by E.R.; software by T.T.; validation by O.A.; formal analysis by G.D.B.; investigation by E.R. and I.Z.; resources by T.T.; data curation by G.D.B. and M.M.G.; writing —original draft preparation by I.Z.; writing-review and editing by O.A.; visualization by I.Z.; supervision J.B.; project administration, by T.T.; funding acquisition, T.T. All authors have read and agreed to the published version of the manuscript.

Funding: The research was supported by the projects SLTKT20427 and SARASWATI 2.0 project and by project No.1.1.1.2/VIAA/3/19/531 "Innovative technologies for stabilization of landfillsdiminishing of environmental impact and resources potential in frames of circular economy".

Institutional Review Board Statement: The study was conducted according to the guidelines of the University of Tartu. Ethical review and approval were waived for this study, due to not involving humans or animals.

Informed Consent Statement: Not applicable.

Data Availability Statement: All authors confirm to data to be available only in current article due to protect study participant privacy.

Acknowledgments: Christina Mürk is acknowledged for the analyses of water samples during reactor operation.

Conflicts of Interest: The authors declare no conflict of interest. The funders had no role in the design of the study; in the collection, analyses, or interpretation of data; in the writing of the manuscript, or in the decision to publish the results.

\section{Abbreviations}

AnAOB Anaerobic ammonium oxidizing bacteria

Anammox Anaerobic ammonium oxidation

AOB Ammonium oxidizing bacteria

AMO Ammonium monooxygenase

ATP Adenosine triphosphate

CANON Complete autotrophic nitrogen removal over nitrite

COD Chemical oxygen demand 


$\begin{array}{ll}\text { DEMON } & \text { Deammonification } \\ \text { DO } & \text { Dissolved oxygen } \\ \text { HAO } & \text { hydroxylamine oxidoreductase } \\ \text { HDH } & \text { Hydrazine dehydrogenase } \\ \text { HZO } & \text { Hydrazine oxidoreductase } \\ \text { HZS } & \text { Hydrazine synthase } \\ \text { MLSS } & \text { Mixed liquor suspended solid } \\ \text { NOB } & \text { Nitrite oxidizing bacteria } \\ \text { TNRR } & \text { Total nitrogen removal rate } \\ \text { TNLR } & \text { Total nitrogen loading rate } \\ \text { TNRE } & \text { Total nitrogen removal efficiency } \\ \text { NirS/NirK } & \text { Nitrite oxidoreductases (k- copper, S- Iron containing) } \\ \text { PCR } & \text { Polymerase chain reaction } \\ \text { RBC } & \text { Rotating biological contractor } \\ \text { rRNA } & \text { Ribosomal Ribonucleic acid } \\ \text { SAA } & \text { Specific anammox activity } \\ \text { SBR } & \text { Sequence Batch Reactor } \\ \text { SNAP } & \text { Single-stage nitrogen removal using anammox and partial nitrification } \\ \text { UASB } & \text { Upflow Anaerobic Sludge Blanket } \\ \text { WWTP } & \text { Wastewater treatment plant }\end{array}$

\section{References}

1. Bulgariu, D.; Axinte, O.; Badescu, I.S.; Stroe, C.; Neacsu, V.; Bulgariu, L. Evolution of Trophic Parameters from Amara Lake. Environ. Eng. Manag. J. 2015, 14, 559-565. [CrossRef]

2. Mandel, A.; Zekker, I.; Jaagura, M.; Tenno, T. Enhancement of anoxic phosphorus uptake of denitrifying phosphorus removal process by biomass adaption. Int. J. Environ. Sci. Technol. 2019, 16, 5965-5978. [CrossRef]

3. Mulder, A.; Van De Graaf, A.; Robertson, L.; Kuenen, J. Anaerobic ammonium oxidation discovered in a denitrifying fluidized bed reactor. FEMS Microbiol. Ecol. 1995, 16, 177-183. [CrossRef]

4. Hu, Z.; Lotti, T.; De Kreuk, M.; Kleerebezem, R.; Van Loosdrecht, M.; Kruit, J.; Jetten, M.S.M.; Kartal, B. Nitrogen Removal by a Nitritation-Anammox Bioreactor at Low Temperature. Appl. Environ. Microbiol. 2013, 79, 2807-2812. [CrossRef]

5. Van Der Star, W.R.; Abma, W.R.; Blommers, D.; Mulder, J.-W.; Tokutomi, T.; Strous, M.; Picioreanu, C.; Van Loosdrecht, M.C. Startup of reactors for anoxic ammonium oxidation: Experiences from the first full-scale anammox reactor in Rotterdam. Water Res. 2007, 41, 4149-4163. [CrossRef]

6. Shalini, S.S.; Joseph, K. Start-up of the SHARON and ANAMMOX process in landfill bioreactors using aerobic and anaerobic ammonium oxidising biomass. Bioresour. Technol. 2013, 149, 474-485. [CrossRef] [PubMed]

7. Strous, M.; Heijnen, J.J.; Kuenen, J.G.; Jetten, M.S.M. The sequencing batch reactor as a powerful tool for the study of slowly growing anaerobic ammonium-oxidizing microorganisms. Appl. Microbiol. Biotechnol. 1998, 50, 589-596. [CrossRef]

8. Kartal, B.; De Almeida, N.M.; Maalcke, W.J.; Camp, H.J.O.D.; Jetten, M.S.; Keltjens, J.T. How to make a living from anaerobic ammonium oxidation. FEMS Microbiol. Rev. 2013, 37, 428-461. [CrossRef] [PubMed]

9. Chamchoi, N.; Nitisoravut, S. Anammox enrichment from different conventional sludges. Chemosphere 2007, 66, 2225-2232. [CrossRef]

10. Quan, Z.-X.; Rhee, S.-K.; Zuo, J.-E.; Yang, Y.; Bae, J.-W.; Park, J.R.; Lee, S.-T.; Park, Y.-H. Diversity of ammonium-oxidizing bacteria in a granular sludge anaerobic ammonium-oxidizing (anammox) reactor. Environ. Microbiol. 2008, 10, 3130-3139. [CrossRef]

11. Zekker, I.; Rikmann, E.; Tenno, T.; Kroon, K.; Seiman, A.; Loorits, L.; Fritze, H.; Tuomivirta, T.; Vabamäe, P.; Raudkivi, M.; et al. Start-up of low-temperature anammox in UASB from mesophilic yeast factory anaerobic tank inoculum. Environ. Technol. 2014, 36, 214-225. [CrossRef] [PubMed]

12. Macé, S.; Mata-Alvarez, J. Utilization of SBR Technology for Wastewater Treatment: An Overview. Ind. Eng. Chem. Res. 2002, 41, 5539-5553. [CrossRef]

13. Laureni, M.; Weissbrodt, D.G.; Villez, K.; Robin, O.; De Jonge, N.; Rosenthal, A.; Wells, G.; Nielsen, J.L.; Morgenroth, E.; Joss, A. Biomass segregation between biofilm and flocs improves the control of nitrite-oxidizing bacteria in mainstream partial nitritation and anammox processes. Water Res. 2019, 154, 104-116. [CrossRef] [PubMed]

14. Zekker, I.; Raudkivi, M.; Artemchuk, O.; Rikmann, E.; Priks, H.; Jaagura, M.; Tenno, T. Mainstream-sidestream wastewater switching promotes anammox nitrogen removal rate in organic-rich, low-temperature streams. Environ. Technol. 2020, 1-10. [CrossRef]

15. Windey, K.; De Bo, I.; Verstraete, W. Oxygen-limited autotrophic nitrification-denitrification (OLAND) in a rotating biological contactor treating high-salinity wastewater. Water Res. 2005, 39, 4512-4520. [CrossRef]

16. Jin, R.-C.; Yang, G.-F.; Yu, J.-J.; Zheng, P. The inhibition of the Anammox process: A review. Chem. Eng. J. 2012, 197, 67-79. [CrossRef] 
17. Cho, S.; Kambey, C.; Nguyen, V.K. Performance of Anammox Processes for Wastewater Treatment: A Critical Review on Effects of Operational Conditions and Environmental Stresses. Water 2019, 12, 20. [CrossRef]

18. Lotti, T.; Van Der Star, W.; Kleerebezem, R.; Lubello, C.; Van Loosdrecht, M. The effect of nitrite inhibition on the anammox process. Water Res. 2012, 46, 2559-2569. [CrossRef]

19. Zekker, I.; Kroon, K.; Rikmann, E.; Tenno, T.; Tomingas, M.; Vabamäe, P.; Vlaeminck, S.E.; Tenno, T. Accelerating effect of hydroxylamine and hydrazine on nitrogen removal rate in moving bed biofilm reactor. Biodegradation 2012, 23, 739-749. [CrossRef]

20. Schalk, J.; Oustad, H.; Kuenen, J.; Jetten, M.S. The Anaerobic Oxidation of Hydrazine: A Novel Reaction in Microbial Nitrogen Metabolism. FEMS Microbiol. Lett. 1998, 158, 61-67. [CrossRef]

21. Ganesan, S.; Vadivelu, V. Effect of external hydrazine addition on anammox reactor start-up time. Chemosphere 2019, 223, 668-674. [CrossRef] [PubMed]

22. Yao, Z.-B.; Cai, Q.; Zhang, D.; Xiao, P.-Y.; Lu, P.-L. The enhancement of completely autotrophic nitrogen removal over nitrite (CANON) by N 2 H 4 addition. Bioresour. Technol. 2013, 146, 591-596. [CrossRef] [PubMed]

23. Xiang, T.; Gao, D. Comparing two hydrazine addition strategies to stabilize mainstream deammonification: Performance and microbial community analysis. Bioresour. Technol. 2019, 289, 121710. [CrossRef] [PubMed]

24. Tenno, T.; Rikmann, E.; Uiga, K.; Zekker, I.; Mashirin, A.; Tenno, T. A novel proton transfer model of the closed equilibrium system $\mathrm{H}_{2} \mathrm{O}-\mathrm{CO}_{2}-\mathrm{CaCO}_{3}-\mathrm{NH}_{\mathbf{X}}$. Proc. Est. Acad. Sci. 2018, 4017, 2. [CrossRef]

25. Tenno, T.; Rikmann, E.; Zekker, I. Modelling the solubility of sparingly soluble compounds depending on their particles size. Proc. Est. Acad. Sci. 2018, 67, 300. [CrossRef]

26. Zekker, I.; Bhowmick, G.D.; Priks, H.; Nath, D.; Rikmann, E.; Jaagura, M.; Tenno, T.; Tämm, K.; Ghangrekar, M.M. ANAMMOXdenitrification biomass in microbial fuel cell to enhance the electricity generation and nitrogen removal efficiency. Biodegradation 2020, 31, 249-264. [CrossRef]

27. Greenberg, A.; Clesceri, L.; Eaton, A. Standard Methods for the Examination of Water and Wastewater, 18th ed.; American Public Health Association Publications: Washington, DC, USA, 1992.

28. Barros, C.M.C.; Jia, M.; Van Loosdrecht, M.C.; Volcke, E.I.; Winkler, M.K. Evaluating the potential for dissimilatory nitrate reduction by anammox bacteria for municipal wastewater treatment. Bioresour. Technol. 2017, 233, 363-372. [CrossRef]

29. Shu, D.; He, Y.; Yue, H.; Gao, J.; Wang, Q.; Yang, S. Enhanced long-term nitrogen removal by organotrophic anammox bacteria under different $\mathrm{C} / \mathrm{N}$ ratio constraints: Quantitative molecular mechanism and microbial community dynamics. RSC Adv. 2016, 6, 87593-87606. [CrossRef]

30. Dapena-Mora, A.; Fernández, I.; Campos, J.; Mosquera-Corral, A.; Méndez, R.; Jetten, M. Evaluation of activity and inhibition effects on Anammox process by batch tests based on the nitrogen gas production. Enzym. Microb. Technol. 2007, 40, 859-865. [CrossRef]

31. Oshiki, M.; Shimokawa, M.; Fujii, N.; Satoh, H.; Okabe, S. Physiological characteristics of the anaerobic ammonium-oxidizing bacterium 'Candidatus Brocadia sinica'. Microbiology 2011, 157, 1706-1713. [CrossRef]

32. Kartal, B.; Koleva, M.; Arsov, R.; Van Der Star, W.; Jetten, M.S.; Strous, M. Adaptation of a freshwater anammox population to high salinity wastewater. J. Biotechnol. 2006, 126, 546-553. [CrossRef] [PubMed]

33. Wu, N.; Zeng, M.; Zhu, B.; Zhang, W.; Liu, H.; Yang, L.; Wang, L. Impacts of different morphologies of anammox bacteria on nitrogen removal performance of a hybrid bioreactor: Suspended sludge, biofilm and gel beads. Chemosphere 2018, 208, 460-468. [CrossRef] [PubMed]

34. Wang, T.; Wang, T.; Gao, D.; Yang, F.; Zhang, G. Comparison between MBR and SBR on Anammox start-up process from the conventional activated sludge. Bioresour. Technol. 2012, 122, 78-82. [CrossRef] [PubMed]

35. Hendrickx, T.L.; Wang, Y.; Kampman, C.; Zeeman, G.; Temmink, H.; Buisman, C.J.N. Autotrophic nitrogen removal from low strength waste water at low temperature. Water Res. 2012, 46, 2187-2193. [CrossRef] [PubMed]

36. Hendrickx, T.L.; Kampman, C.; Zeeman, G.; Temmink, H.; Hu, Z.; Kartal, B.; Buisman, C.J.N. High specific activity for anammox bacteria enriched from activated sludge at $10^{\circ} \mathrm{C}$. Bioresour. Technol. 2014, 163, 214-221. [CrossRef] [PubMed]

37. De Clippeleir, H.; Vlaeminck, S.E.; De Wilde, F.; Daeninck, K.; Mosquera, M.; Boeckx, P.; Verstraete, W.; Boon, N. One-stage partial nitritation/anammox at 15 A degrees $C$ on pretreated sewage: Feasibility demonstration at lab-scale. Appl. Microbiol. Biot. 2013, 97, 10199-10210. [CrossRef]

38. Arroyo, J.M.C.; Sun, W.; Sierra-Alvarez, R.; A Field, J. Inhibition of anaerobic ammonium oxidizing (anammox) enrichment cultures by substrates, metabolites and common wastewater constituents. Chemosphere 2013, 91, 22-27. [CrossRef]

39. Bettazzi, E.; Caffaz, S.; Vannini, C.; Lubello, C. Nitrite inhibition and intermediates effects on Anammox bacteria: A batch-scale experimental study. Process. Biochem. 2010, 45, 573-580. [CrossRef]

40. Strous, M.; Fuerst, J.A.; Kramer, E.H.M.; Logemann, S.; Muyzer, G.; Van De Pas-Schoonen, K.T.; Webb, R.M.T.; Kuenen, J.G.; Jetten, M.S.M. Missing lithotroph identified as new planctomycete. Nature 1999, 400, 446-449. [CrossRef] 
41. Xiao, P.; Lu, P.; Zhang, D.; Han, X.; Yang, Q. Effect of trace hydrazine addition on the functional bacterial community of a sequencing batch reactor performing completely autotrophic nitrogen removal over nitrite. Bioresour. Technol. 2015, 175, 216-223. [CrossRef]

42. Zekker, I.; Kivirüüt, A.; Rikmann, E.; Mandel, A.; Jaagura, M.; Tenno, T.; Artemchuk, O.; Rubin, S.D.; Tenno, T. Enhanced Efficiency of Nitritating-Anammox Sequencing Batch Reactor Achieved at Low Decrease Rates of Oxidation-Reduction Potential. Environ. Eng. Sci. 2019, 36, 350-360. [CrossRef] 